\title{
ПСИХОЛОГІЧНІ ОСОБЛИВОСТІ РОЗВИТКУ ЕМПАТІЇ УЧАСНИКІВ ШКІЛЬНИХ ЛІТЕРАТУРНИХ СТУДІЙ
}

\author{
Ірина Гречуха \\ аспірантка кафедри психології розвитку та консультування \\ Житомирський державний університет імені Івана Франка \\ 10008, Україна, Житомир, вул. Велика Бердичівська, 40 \\ irinagreczucha@gmail.com, https://orcid.org/0000-0002-1704-4320
}

\section{Анотація}

Стаття присвячена аналізу роботи школи 3 літературно обдарованими дітьми. Розвиток літературних здібностей учнів забезпечується як самим навчальним процесом, так і $€$ можливим в позанавчальний час. 3'ясовано, що більшу спрямованість на розвиток творчого потенціалу школярів у літературній діяльності мають різноманітні літературні осередки: шкільні літературні гуртки та факультативи, міські та обласні літературні гуртки та студії. Проаналізовано основні їх завдання та методи роботи 3 літературно обдарованими дітьми. Основну увагу звернено на проблему розвитку емпатії старшокласників, які займаються літературною діяльністю. Охарактеризовано ранній юнацький вік як сприятливий період для розвитку емпатійності. У статті розкрито сутність таких психологічних категорій, як: «емпатія», «емпатійність», «літературні здібності», «освітнє розвивальне середовище», «літературна студія». Проаналізовано діагностичні можливості методів вивчення емпатії у ранньому юнацькому віці. Констатовано, що ефективність літературної діяльності забезпечується певним емпатійним фоном. Зі свого боку кожен рівень розвитку літературних здібностей має свої переважні форми емпатійного реагування, які забезпечують «продуктивність» цього рівня. Описуються результати емпіричного дослідження особливостей розвитку емпатії старшокласників (iі форм та рівнів розвитку, проявів емпатійного реагування до різних об'єктів емпатії), які є учасниками шкільних літературних студій, та тих, які надають перевагу самостійному розвитку своїх літературних здібностей. Емпіричним шляхом з'ясовано, що долучення школярів до літературно-творчого колективу сприяє розвитку їхніх літературних здібностей. Розвиток емпатії у ранньому юнацькому віці дає можливість літературно обдарованим школярам через літературну творчість проявити свою найвищу емпатійність.

Ключові слова: емпатія, емпатійність, літературні здібності, освітнє розвивальне середовище, літературна студія.

\section{Вступ}

В сучасних умовах становлення та розвитку державності в Україні виникла потреба у нових, креативних, обдарованих, активних, інтелектуальних, духовно свідомих громадянах. Тому перед сучасною системою освіти стоїть завдання у виявленні обдарованих дітей та молоді та забезпеченні сприятливих умов для їхнього особистісного зростання й творчої самореалізації, формування у них активного пізнавального та творчого інтересу до розвитку їхніх творчих здібностей. 
Розвиток літературних здібностей учнів забезпечується як самим навчальним процесом (під час уроків української мови, української та зарубіжної літератури), так і є можливим в позанавчальний час. На уроках літератури учні не лише знайомляться 3 різними художніми творами письменників сучасності та минулого, але й роблять свої перші спроби в літературній діяльності (виконують різноманітні творчі завдання, пишуть твори на вільну тематику та тематику, задану вчителем тощо). Більшу спрямованість на розвиток їхнього творчого потенціалу в літературній діяльності мають різноманітні літературні осередки (шкільні літературні гуртки та факультативи, міські та обласні літературні гуртки та студії), робота яких проводиться у позанавчальний час учнів. Основними їхніми завданнями $є$ формування та розвиток у літературно обдарованих дітей основних компонентів літературних здібностей, а також у здійсненні творчого підходу до аналізу літературних творів, розвитку більш точного та виразного мовлення у дітей.

Проте, як зазначає В. Ягункова (Ягункова, 1973: 175), повноцінне сприйняття художнього тексту не можливе без розвитку деяких психологічних якостей у школярів. Такими є: емоційна сприйнятливість, образне мислення, творча уява, легкість у перетворенні своїх думок та емоцій у словесну форму, тощо, що і є, зі слів дослідниці, основними складовими літературних здібностей. Як бачимо, емоційний компонент відіграє важливе значення у структурі літературних здібностей. А саму емоційну сприйнятливість (чуйність, чутливість) вчені розглядають як своєрідну готовність людини відгукнутися на різного роду переживання, спрямовані «на себе», «на інших», «на природу», «на твори мистецтва» тощо (Ильин, 2001). Отже, ми наголошуємо належність емоційної сприйнятливості до емпатійних здібностей.

Розвитку емпатії у системі розвитку літературних здібностей надається важливе значення (Є. Громов, О. Ковальов, О. Нікіфорова, П. Медведєв). Емпатійні здібності не лише допомагають адекватному сприйняттю художніх творів письменників, але й полегшують та уможливлюють власну літературну діяльність школярів. Тому важливо створити таке освітнє середовище, яке б сприяло розвитку їхньої емпатійності, що і $є$ предметом нашого дослідження.

Створення освітнього середовища, яке було 6 сприятливим для розвитку обдарованої дитини, є психолого-педагогічною проблемою, а тому стало предметом дослідження багатьох педагогів (Ш. Амонашвілі, В. Водовозов, М. Пирогов, С. Русова, М. Рибникова, В. Сухомлинський та ін.) та психологів (Д. Корольов, Г. Костюк, М. Мельник, Р. Семенова, М. Сніжна, Д. Вантассел-Баскі, Д. Стенлі, Дж. Рензуллі, Р. Стернберг, Дж. Фельдштейн та ін.).

Шкільна система освіти не має можливості повною мірою реалізувати творчий потенціал дитини. А тому створюється система додаткових позанавчальних осередків (гуртків, факультативів, секцій, клубів тощо), мета яких і полягає у забезпеченні сприятливого середовища до розвитку їхніх творчих здібностей та обдарованості. 3 точки зору психології, таке освітнє розвивальне середовище має бути особистіснозорієнтованим, а система взаємодії «учень - вчитель» має забезпечувати всіх учасників освітнього процесу можливістю бути суб'єктом власного розвитку. У такий спосіб між вчителем та учнем також налагоджуються суб'єкт-суб'єктні взаємини, які грунтуються на співпраці та довірі, а соціальна роль «вчителя» змінюється на роль творчого «наставника», «керівника» гуртка чи факультативу. 
Однак важливо зважати на те, що сприятливе освітнє середовище надає лише можливість до розвитку обдарованості, але не $є$ іiі гарантом. Багаторічні дослідження розвитку обдарованих дітей показали, що в основі творчих досягнень учнів лежить їхня власна пізнавальна та творча активність, що не є безпосереднім результатом біологічної та соціальної зумовленості. Таке освітнє середовище надає лише шанс для розвитку обдарованості, а використати його чи залишити нереалізованим $\epsilon$ вибором дитини (Семенова, 2012).

Таким сприятливим освітнім середовищем для літературно обдарованих школярів (або ж тих, хто проявляє ознаки літературної обдарованості) є різноманітні літературні осередки: шкільні літературні гуртки та факультативи, міські та обласні літературні гуртки та студії. Нам варто вказати на основні відмінності у їхній роботі, оскільки, як вказує В. Коваленко (Коваленко, 2006), навіть вчителі-словесники не завжди диференціюють поняття «літературний гурток» і «літературна студія» та використовують їх як синоніми. Насправді, відмінності криються у змісті їхньої роботи: якщо робота літературного гуртка спрямована на сприяння творчому зростанню особистості дитини через поглиблене вивчення літератури загалом, то діяльність літературної студії (або, як їх ще називають, «літературно-творчої студії») передбачає розвиток літературних здібностей дітей, які вже мають власні художні твори або проявляють бажання у їх написанні, а також мають потребу педагогічного супроводу у конструюванні їхнього літературного досвіду як майбутнього письменника. Формами роботи у таких студіях може бути як індивідуальна (написання науково-дослідних робіт, підготовка та друк творчих доробків тощо), так і групова (групові заняття учасників студії, різноманітні екскурсії (на природу, до бібліотеки, театру, на мистецькі виставки тощо), зустрічі із письменниками та членами інших студій, виступи на літературних вечорах тощо).

Особливістю роботи літературних студій $€$ й те, що дитина разом зі своїм літературним наставником створюють програму «саморуху» в розвитку іiі літературних здібностей. На літстудійних заняттях учасники знайомляться із правилами літературного творення, виконують різноманітні творчі завдання, перебувають у літературному пошуку нових ідей та тем, нових художніх образів. Також заняття передбачають колективний аналіз нових літературних творів іiі учасників. Таке спільне редагування художніх творів не лише сприяє розвитку їхніх літературних здібностей, але й формує уміння висловити власну оцінку щодо творчості своїх однолітків, виховує почуття самокритики та самовимогливості (Коваленко, 2006).

Окрім включення школярів у літературно-творчий колектив (С. Кудрявцева, Ю. Львова, В. Ягункова), до сприятливих педагогічних умов розвитку літературних здібностей належать й: розширення чуттєвого, інтелектуального та морально-етичного досвіду (Є. Корсунський, М. Рибникова, В. Сухомлинський); ведення літературних щоденників та записників (П. Білоус, В. Сухомлинський); доступність та зацікавленість у темі твору, який задається літературним керівником (П. Блонський, Л. Виготський); вплив особистості літературного керівника та наставника (С. Корсунський, Ю. Львова).

Літературні здібності ми розглядаємо як системне утворення, яке перебуває у постійному динамічному розвитку та якісних змінах й має свою структуру (компоненти та рівні розвитку), психологічні механізми та чинники розвитку (Журавльова \& Гречуха, 2018). Всі названі вище фактори зараховуємо до зовнішніх педагогічних чинників 
розвитку літературних здібностей школярів, проте не менш важливими $\epsilon$ вплив психологічних та особистісних детермінант розвитку літературно творчої особистості. Однією із внутрішніх умов розвитку літературних здібностей є емпатія. Літературна творчість майбутніх письменників відбувається на фоні їхніх емпатійних переживань, що супроводжує їх на всіх етапах творчого процесу.

Ефективність літературної діяльності забезпечується певним емпатійним фоном. Кожен рівень розвитку літературних здібностей має свої переважні форми емпатійного реагування, які забезпечують «продуктивність» цього рівня. Перехід на вищий рівень розвитку літературних здібностей передбачає й перехід до «вищих форм» емпатії.

Результати дослідження (Журавльова \& Гречуха, 2018) показали, що у школярівпочатківців переважними формами емпатійного реагування $\epsilon$ «Реальне сприяння» $(\overline{\mathrm{x}}=5,0)$ та «Індиферентність» ( $\bar{x}=3,3)$. Звідси, учні з невеликим досвідом літературної діяльності майже однаковою мірою схильні проявляти як реальне сприяння об'єктові емпатійного процесу, так і байдужість та невтручання, готовність перекласти відповідальність за ситуацію на когось іншого. Це говорить про те, що школяр, який робить перші спроби в літературній діяльності, може швидко «заражатися» емоціями та переживаннями інших людей, красою природи, архітектури тощо. А далі, в результаті акумулювання всіх цих емоційних переживань в собі, відбувається, за Л. Журавльовою (Журавльова, 2007), «замкнення» на власній особистості. Проте літературна діяльність передбачає певний вихід такої «енергії» через сублімований продукт творчості - літературний твір. Авжеж, 3 огляду на недостатній розвиток всіх компонентів літературних здібностей (мовленнєвого, мотиваційного, ціннісно-світоглядного тощо), ці «спроби» не досконалі, але на цьому етапі їх розвитку такий механізм є виправданим та результативним.

Натомість у школярів із ознаками літературної обдарованості переважають такі форми емпатійного реагування як «Альтруїзм» $(\overline{\mathrm{x}}=4,8)$ та «Реальне сприяння» $(\overline{\mathrm{x}}=3,8)$ (Журавльова \& Гречуха, 2018). Ці форми емпатії мають можливість реалізуватися в їхній літературній творчості. Це вже не прямий витік емоційних переживань учня. Художній твір стає більш обдуманим, спланованим, виваженим, із чітко окресленими всіма художніми лініями та сюжетом, в основі якого прослідковується основна ідея твору. Крім того, зважаючи на специфіку цього виду діяльності, сам літературний твір і $є$ проявом конативної складової емпатії, тобто є специфічною «відповіддю» на певну емпатогенну ситуацію (старшокласники часто порушують соціальні та моральні проблеми у своїй творчості).

Окрім того, емпатія є цілісне, ієрархічно структуроване утворення, що має свої рівні відображення переживань: неусвідомлений (фізіологічний), певною мірою усвідомлений (психофізіологічний), усвідомлений (соціопсихологічний) і надсвідомий (духовний) (Журавльова, 2007). Ці рівні емпатійного реагування проявляються і в літературно обдарованих особистостей. Саме в ранньому юнацькому віці можна говорити про «...становлення емпатійності як вікової особливості особистості. В юнацькому віці емпатія стає інтегральною характеристикою особистості, в якій проявляється її ставлення до світу, людей і до власної особи» (Журавльова, 2007: 188). Так, старшокласникам стає доступний найвищий рівень відображення переживань - духовний рівень. Авжеж, кожен iз цих рівнів емпатійного переживання може стати для майбутнього письменника джерелом до створення нового художнього образу. Проте лише на найвищому, духовному 
рівні емпатуючий здатен осягнути глибокі емоційні переживання емпата, його систему цінностей та життєвих орієнтирів та передати їх через художні засоби в своєму літературному творі.

Мета дослідження - вивчення особливостей розвитку емпатії учасників шкільних літературних студій. Завдання дослідження: порівняння особливостей розвитку емпатії старшокласників (ії форм та рівнів розвитку), які $є$ учасниками шкільних літературних студій, та тих, які надають перевагу самостійному розвитку своїх літературних здібностей.

\section{Методи дослідження}

Дослідницьким матеріалом для вивчення особливостей розвитку емпатії учасників шкільних літературних студій стали емпіричні результати, отримані впродовж 20182019 рр. на базі Житомирської загальноосвітньої школи I-III ступенів №26, ліцею №25 м. Житомира та Житомирської міської гуманітарної гімназії №23 ім. М. Очерета. У дослідженні взяли участь 28 учнів 9-11 класів, які займаються літературною творчістю та мають відповідні досягнення. До вибірки ввійшли старшокласники, які мають різний рівень розвитку літературних здібностей і які є учасниками шкільних літературних студій (10 осіб), а також ті, які надають перевагу самостійному розвитку своїх літературних здібностей (18 осіб). Дослідження особливостей розвитку емпатії старшокласників здійснювалося за допомогою методик «Тест на емпатію для підлітків та юнаків» (Журавльова, 2010) та «Діагностика рівня полікомунікативної емпатії» (Диагностика уровня поликоммуникативной эмпатии..., 2002).

Досліднищькі гіпотези: рівень розвитку емпатії у школярів, які займаються літературною діяльністю у шкільних літературних студіях, $\epsilon$ вищим, порівняно зі школярами, які займаються самостійно; прослідковуються відмінності у показниках форм емпатійного реагування між групами досліджуваних школярів-літстудійців та школярів, які займаються самостійним розвитком своїх літературних здібностей; існують відмінності в ієрархічній системі показників емпатії щодо ії об'єктів (емпатів).

\section{Результати та дискусії}

Рівень розвитку емпатії та форми емпатійного реагування вивчалися за допомогою «Тесту на емпатію для підлітків та юнаків» Л. Журавльової (Журавльова, 2010). Досліджуваним учням пропонувалося ознайомитися із п'ятнадцятьма різноманітними емпатогеними ситуаціями та пригадати свої емоційні й поведінкові реакції, зважаючи на свій життєвий досвід, або ж спрогнозувати їх, якби такі трапилися. 3 цією метою до кожної ситуації було надано по сім варіантів можливих виборів, а також можливість додати власний варіант розв'язання проблеми. Результати дослідження представлено у таких шкалах (формах емпатіі): «Антиемпатія», «Індиферентність», «Співпереживання», «Співчуття», «Внутрішнє сприяння» (пасивна емпатія), «Реальне сприяння не на шкоду собі», «Реальне сприяння на шкоду собі (альтруїзм)» і загального інтегрального показника рівня розвитку емпатії.

Дослідження показників емпатії щодо ії об’єктів (емпатів) у школярів-літстудійців та школярів, які займаються літературною творчістю самостійно, вивчалися за допомогою методики «Діагностика рівня полікомунікативної емпатії» I. Юсупова (Диагностика уровня поликоммуникативной эмпатии..., 2002). Автор називає шість можливих об'єктів, 
до яких досліджуванні можуть проявити свої емпатійні переживання: «батьки», «тварини», «літні люди», «діти», «герої художніх творів» та «незнайомі або малознайомі люди». Як бачимо, ця методика містить групу «герої художніх творів», що робить для нас iii винятково цінною. Особливістю нашої вибірки $\epsilon$ те, що вони самі $\epsilon$ авторами літературних творів (роблять перші спроби в літературній творчості), а тому мають (гіпотетично) проявляти високу емпатійність до цієї групи емпатів.

Статистична обробка даних здійснювалася за допомогою методів порівняльного аналізу середніх показників та t-критерію Стьюдента для незалежних вибірок.

За результатами вивчення рівня розвитку емпатії учасників шкільних літературних студій за методикою «Тест на емпатію для підлітків та юнаків» Л. Журавльової були виявленні такі тенденції: більшість школярів (70\%) мають високий рівень розвитку емпатії; у 30\% досліджуваних проявляється середній рівень. 3 дуже високим, дуже низьким рівнем емпатії та антиемпатією школярів не виявлено. У школярів, які займаються самостійно розвитком своїх літературних здібностей, спостерігається переваги середнього рівня розвитку емпатії (70\%). Високий рівень емпатії проявляють $10 \%$ учнів та 20\% проявляють низький. Як і в попередній групі досліджуваних, з дуже низьким рівнем емпатії та антиемпатією школярів не виявлено. Обрахування t-критерію Стьюдента для незалежних вибірок показало високу статистичну значущість $(\mathrm{p}<0,001)$ між показниками рівня розвитку інтегральної емпатії між групами досліджуваних школярів-літстудійців та школярів, які самостійно займаються розвитком своїх літературних здібностей. Як бачимо, школярі, які займаються у літературних студіях, демонструють вищий рівень розвитку емпатії (табл. 1).

Таблиия 1

Особливості розвитку емпатії старшокласників (у \%)

\begin{tabular}{|c|c|c|c|c|c|c|c|}
\hline \multirow[b]{2}{*}{ Характеристика вибірки } & \multicolumn{7}{|c|}{ Рівень розвитку емпатії } \\
\hline & 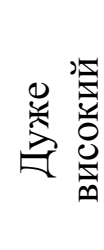 & 离 & 䢘 & 苞 & 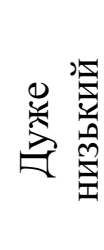 & 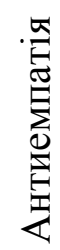 & 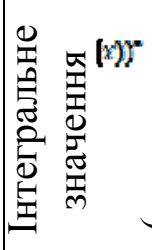 \\
\hline $\begin{array}{l}\text { Досліджуванні, які займаються } \\
\text { літературною творчістю у } \\
\text { літературних студіях }\end{array}$ & 0 & 70 & 30 & 0 & 0 & 0 & 51,8 \\
\hline $\begin{array}{l}\text { Досліджуванні, які займаються } \\
\text { літературною творчістю самостійно }\end{array}$ & 0 & 10 & 70 & 20 & 0 & 0 & 34,76 \\
\hline
\end{tabular}

На наступному етапі дослідження вивчались відмінності у показниках форм емпатійного реагування. Достовірні відмінності між групами досліджуваних школярівлітстудійців та школярів, які самостійно займаються розвитком своїх літературних здібностей, виявлено між показниками таких форм емпатії: «Антиемпатія» $(\mathrm{p}<0,05)$, «Індиферентність» $(\mathrm{p}<0,04)$, «Реальне сприяння не на шкоду собі» $(\mathrm{p}<0,04)$, «Реальне сприяння на шкоду собі (альтруїзм)» $(\mathrm{p}<0,04)$. 
Ієрархічна система середніх значень показників вираження форм емпатії школярівлітстудійців така: «Реальне сприяння» $(5,6)$, «Альтруїзм» $(4,8)$, «Внутрішнє сприяння» $(1,5)$, «Індиферентність» $(1,0), \quad$ «Співчуття» $(1,0)$, «Співпереживання» $(0,7)$ та «Антиемпатія» $(0,4)$ (табл. 2). Домінуючими формами емпатії в цій групі досліджуваних $\epsilon$ «Реальне сприяння не на шкоду собі» та «Реальне сприяння на шкоду собі», що може свідчити про їхню чуйність та схильність до прояву емоцій, активну життєву позицію та схильність до альтруїзму. Ці ж форми емпатії мають можливість реалізуватися в їхній літературній творчості, оскільки часто старшокласники-літстудійці порушують соціально значущі теми.

У школярів, які займаються самостійним розвитком своїх літературних здібностей, спостерігається така ієрархія середніх значень показників форм прояву емпатії: «Реальне сприяння» $(4,53)$, «Альтруїзм» $(2,8)$, «Індиферентність» $(2,8)$, «Внутрішнє сприяння» $(1,53)$, «Антиемпатія» $(1,24)$, «Співчуття» $(1,0)$ та «Співпереживання» $(1,0)$ (див. табл. 2). Домінуючою формою емпатії в цій групі досліджуваних $є$ «Реальне сприяння не на шкоду собі». Також однаковою мірою проявилися «Реальне сприяння на шкоду собі (альтруїзм)» та «Індиферентність (байдужість)», що може свідчити про несформованість чіткої життєвої позиції. Тому, залежно від ситуації, такі старшокласники проявляють реальне сприяння та готовність надати допомогу об'єктові, який іiі потребує, та байдужість, обираючи стратегію невтручання, готові перекласти відповідальності за ситуацію на когось іншого.

Таблиия 2

Особливості прояву форм емпатійного реагування старшокласників $(x))^{-}$

\begin{tabular}{|c|c|c|c|c|c|c|c|}
\hline \multirow[b]{2}{*}{ Характеристика вибірки } & \multicolumn{7}{|c|}{ Форми емпатії } \\
\hline & 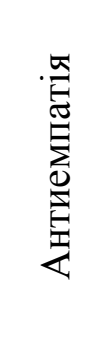 & 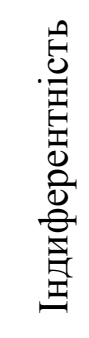 & 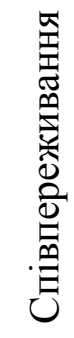 & 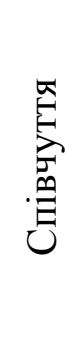 & 蛋䛒 & 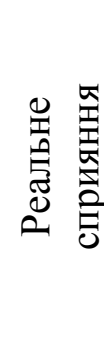 & 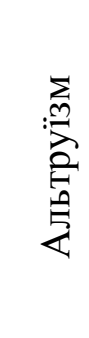 \\
\hline $\begin{array}{l}\text { Досліджуванні, які займаються } \\
\text { літературною творчістю у } \\
\text { літературних студіях }\end{array}$ & 0,4 & 1,0 & 0,7 & 1,0 & 1,5 & 5,6 & 4,8 \\
\hline $\begin{array}{l}\text { Досліджуванні, які займаються } \\
\text { літературною творчістю самостійно }\end{array}$ & 1,24 & 2,82 & 1,0 & 1,0 & 1,53 & 4,53 & 2,82 \\
\hline
\end{tabular}

На останньому етапі дослідження перевірялася третя частина нашої гіпотези. Згідно з результатами дослідження, ієрархічна система середніх значень показників емпатії щодо іiі об'єктів (емпатів) в учнів, які займаються літературною творчістю самостійно, така: «батьки», «незнайомі або малознайомі люди», «герої художніх творів», «тварини», «діти» та «літні люди». Ієрархічна система середніх значень показників емпатійного реагування в учнів-студійців є дещо іншою: «батьки», «тварини», «незнайомі або малознайомі люди», «герої художніх творів», «діти» та «літні люди» (табл. 3). 
Таблиия 3

Показники емпатійного реагування старшокласників до різних об'сктів емпатії

\begin{tabular}{|l|c|c|}
\hline \multicolumn{1}{|c|}{ Об'єкти емпатії } & $\begin{array}{c}\text { Середні значення показників } \\
\text { за шкалами учнів-студійців } \\
\left.\text { (при } \mathrm{x}_{\max }=15\right)\end{array}$ & $\begin{array}{c}\text { Середні значення показників за } \\
\text { шкалами учнів, які займаються } \\
\text { літературною творчістю } \\
\text { самостійно (при х } \max =15)\end{array}$ \\
\hline Батьки & 11,30 & 10,52 \\
\hline Тварини & 9,80 & 8,29 \\
\hline Літні люди & 6,80 & 6,52 \\
\hline Діти & 9,20 & 8,11 \\
\hline Герої художніх творів & 9,50 & 8,71 \\
\hline $\begin{array}{l}\text { Незнайомі або } \\
\text { малознайомі люди }\end{array}$ & 9,60 & 9,88 \\
\hline
\end{tabular}

Ми спостерігаємо низьку статистичну значущість (p>0,1) відмінностей у показниках емпатійного реагування до різних об'єктів емпатії між групами учнівлітстудійців та учнів, які займаються літературною творчістю самостійно. Хоча показники за шкалами у школярів, які займаються у літературних студіях, вищі (див. табл. 3), однак не так, щоб це визначало їхню відмінність з групою школярів, які займаються розвитком своїх літературних здібностей самостійно. Такий широкий діапазон об'єктів емпатійного реагування може свідчити про їхні вікові особливості (їхню чутливістю, емоційністю, 3 деякими проявами максималізму у вимогах до себе та оточуючих людей) та те, що вони мають можливість проявити себе в одному виді творчості.

\section{Висновки}

1. Долучення школярів до літературно-творчого колективу сприяє розвитку їхніх літературних здібностей. А розвиток емпатії у ранньому юнацькому віці дає можливість літературно обдарованому учневі через літературну творчість проявити свою найвищу емпатійність.

2. Рівень розвитку емпатії у школярів, які займаються розвитком своїх літературних здібностей у літературних студіях, $є$ вищим, порівняно зі школярами, які їх розвивають самостійно.

3. Існують достовірні відмінності у групах досліджуваних старшокласників між домінуючими формами емпатії. У школярів-літстудійців переважать такі форми емпатійного реагування як «Реальне сприяння не на шкоду собі» та «Альтруїзм», а у школярів, які займаються літературною творчістю самостійно, «Реальне сприяння не на шкоду собі», «Індиферентність (байдужість)» та «Альтруїзм».

4. Існують несуттєві відмінності в ієрархічній системі показників емпатії щодо іiі об'єктів (емпатів). Літературно творчі старшокласники мають можливість проявити свою вищу емпатійність не лише до реальних персонажів, а й до героїв художніх творів.

Перспективою подальших досліджень є розробка та апробація програми розвитку емпатії у старшокласників, які мають літературні здібності, з метою їх особистісного та творчого розвитку. 


\section{Література}

1. Журавльова, Л.П. (2007). Психологія емпатія. (Монографія). Житомир : Вид-во ЖДУ ім. І. Франка.

2. Журавльова, Л. (2010). Діагностика емпатії та іiі форм у підлітковому та юнацькому віці. Науковий часопис Начіонального педагогічного університету імені М.П. Драгоманова. Серія 12: Психологічні науки, 31(55), 154-161.

3. Журавльова, Л., \& Гречуха, I. (2018). Дослідження особливостей розвитку емпатії в літературно обдарованих старшокласників. Science and Education a New Dimension. Pedagogy and Psychology, VI(73), 64-69. https://doi.org/10.31174/SEND-PP2018-175V173$\underline{15}$

4. Ильин, Е.П. (2001). Эмоччии и чувства. Санкт-Петербург : Питер.

5. Коваленко, В.М. (2006). Поетичний гербарій: літературно-творча студія: Метод. посібник. Черкаси : Брама-Україна.

6. Костюк, Г.С. (1989). Навчально-виховний процес $і$ психічний розвиток особистості. Л.М. Проколієнко (Ред.). Київ : Радянська школа.

7. Семенова, Р.О. (2012). Концептуальні основи побудови освітнього середовища для обдарованих дітей та молоді. С.Д. Максименко \& Р.О. Семенова (Ред.), Актуальні проблеми психології (Т. 6/8, с. 5-22). Житомир : Вид-во ЖДУ імені Івана Франка.

8. Юсупов, И.М. (2002). Диагностика уровня поликоммуникативной эмпатии. Н.П. Фетискин, В.В. Козлов \& Г.М. Мануйлов (Ред.), Социиально-психологическая диагностика развития личности и мальх групn (с. 153-156). Москва : Изд-во Института Психотерапии.

9. Ягункова, В.П. (1973). Формирование компонентов литературных способностей у школьников V класса. В.А. Крутецкий (Ред.), Вопросы психологии способностей. Сборник статей (с. 175-214). Москва : Педагогика.

\section{References}

1. Zhuravlova, L.P. (2007). Psykholohiia empatii [Psychology of empathy]. Zhytomyr : Vyd-vo ZhDU im. I. Franka [in Ukrainian].

2. Zhuravlova, L. (2010). Diahnostyka empatii ta yii form u pidlitkovomu ta yunatskomu vitsi [Diagnosis of empathy and its forms in adolescence and adolescence]. Naukovyi chasopys Natsionalnoho pedahohichnoho universytetu imeni M. P. Drahomanova. Seriia 12: Psykholohichni nauky - Scientific journal of the National Pedagogical Drahomanov University. Series 12: Psychological Sciences, 31(55), 154-161 [in Ukrainian].

3. Zhuravlova, L., \& Hrechukha, I. (2018). Doslidzhennia osoblyvostei rozvytku empatii v literaturno obdarovanykh starshoklasnykiv [Research of features of development of empathy in literary gifted high school students]. Science and Education a New Dimension. Pedagogy and Psychology, VI (73), 64-69. https://doi.org/10.31174/SEND-PP2018-175V173-15 [in Ukrainian].

4. Il'in, E.P. (2001). Emotsii i chuvstva [Emotions and feelings]. Sankt-Peterburg : Piter [in Russian].

5. Kovalenko, V.M. (2006). Poetychnyi herbarii: literaturno-tvorcha studiia [Poetic Herbarium: Literary and Creative Studio]. Cherkasy : Brama-Ukraina [in Ukrainian].

6. Kostiuk, H.S. (1989). Navchalno-vykhovnyi protses i psykhichnyi rozvytok osobystosti [Educational process and mental development of the individual]. L.M. Prokoliienko (Eds.). Kyiv : Rad. shkola [in Ukrainian].

7. Semenova, R.O. (2012). Kontseptualni osnovy pobudovy osvitnoho seredovyshcha dlia obdarovanykh ditei ta molodi [Conceptual frameworks for building an educational environment for gifted children and young people]. In S.D. Maksymenko \& R.O. Semenova (Eds.), Aktualni problemy psykholohii - Topical problems of psychology (T. 6/8, pp. 5-22). Zhytomyr : Vyd-vo ZhDU imeni Ivana Franka [in Ukrainian]. 
8. Jusupov, I.M. (2002). Diagnostika urovnja polikommunikativnoj jempatii [Diagnostics of the level of multicommunicative empathy]. In N. P. Fetiskin, V. V. Kozlov \& G. M. Manujlov (Eds.), Social'no-psihologicheskaja diagnostika razvitija lichnosti i malyh grupp - Sociopsychological diagnosis of the development of personality and small groups (pp. 153-156). Moscow : Izd-vo Instituta Psihoterapii [in Russian].

9. Jagunkova, V.P. (1973). Formirovanie komponentov literaturnyh sposobnostej u shkol'nikov V klassa [The formation of the components of literary ability in students of grade 5]. In V.A. Kruteckij (Eds.), Voprosy psihologii sposobnostej. Sbornik statej - Questions of psychology of abilities. Digest of articles (pp. 175-214). Moscow : Pedagogika [in Russian].

\title{
PSYCHOLOGICAL PECULIARITIES OF EMPATHY DEVELOPMENT OF PARTICIPANTS IN SCHOOL LITERARY STUDIES Iryna Hrechuha
}

Postgraduate student of the Department of Developmental Psychology and Counseling Zhytomyr Ivan Franko State University 40, Velyka Berdychivska Str., Zhytomyr, Ukraine, 10008 irinagreczucha@gmail.com, https://orcid.org/0000-0002-1704-4320

\begin{abstract}
The article is devoted to the analysis of school work with literary gifted children. The development of students' literary abilities is ensured both by the learning process itself and is possible outside of school hours. It is found that a variety of literary centers have a greater focus on the development of students' creative potential in literary activity: school literature circles and electives, city and regional literary circles and studios. Their main tasks and methods of working with literary gifted children are analyzed. More attention is paid to the peculiarities of developing the empathy of high school students engaged in literary activity. The early adolescence is characterized as a favorable period for the development of empathy. The article describes the essence of such psychological categories as: «empathy», «empathetic», «literary ability», «educational development environment», «literary studio». Diagnostic possibilities of methods of studying empathy in early adolescence are analyzed. It is established that the effectiveness of literary activity is provided by a certain empathic background. In turn, each level of development of literary abilities has its own predominant forms of empathic response, which provide «efficiency» of this level. The results of the empirical study of the features of the development of high school students' empathy are described (its forms and levels of development, manifestations of empathic response to various objects of empathy), who are participants in school literary studies and who prefer to develop their literary abilities independently. It is empirically established that the inclusion of students in the literary and creative team promotes the development of their literary abilities. The development of empathy in early adolescence enables literary gifted students to express their highest empathy through literary creativity.
\end{abstract}

Keywords: empathy, literary ability, educational development environment, literary studio.

Подано 13.12.2019

Рекомендовано до друку 20.12.2019 